\title{
Impact of customer trust toward loyalty: the mediating role of perceived usefulness and satisfaction
}

\author{
Anshar Daud \\ Universitas Diponegoro and STIE Nobel Indonesia, Makassar, Indonesia \\ Naili Farida \\ Univeritas Diponegoro, Indonesia \\ Andriyansah \\ Universitas Terbuka, Indonesia \\ Mashur Razak \\ STIMIK Handayani, Makassar, Indonesia
}

\begin{abstract}
Keywords
IPTV, Perceived Ease of Use, Perceived Usefulness, Trust, Satisfaction, Loyalty.
\end{abstract}

\begin{abstract}
The technology of ICT is dynamically developing with sorts of innovative product, one of them is IPTV. Its existence provides triple play multimedia convergence such as telephone, internet and digital TV contents. The customer's adoption on it becomes important toward the service provider for a number of interests, especially for the field of marketing. By means of TAM concept (Technology Acceptance Model) from Gefen et al. (2003) and by adding satisfaction and loyalty so the new model is able to be used to evaluate the response of cognitive, conative and affective of customer. Empirical study applied to the customer's of PT. Telekomunikasi Indonesia, Tbk. in order to test 6 hypotheses as recommended. The Simulation of conceptual model and empirical data research acquired by using of AMOS software indicates that all of the hypotheses proved positively significant. Variable trust is a good antecedent of perceived usefulness, satisfaction and loyalty constructs. Besides that, there is a direct effect between trust with loyalty or indirect effect through the mediation on perceived usefulness and or satisfaction.
\end{abstract}

Corresponding author: Anshar Daud

Email addresses for corresponding author: anshar@stienobel-indonesia.ac.id

First submission received: $6^{\text {th }}$ March 2018

Revised submission received: $2^{\text {nd }}$ May 2018

Accepted: $22^{\text {nd }} 2018$

\section{Introduction}

ICT Industries (Information and Communication Technology) is loaded with rapid progress from time to time. A change in this field is thought to be more quickly in the last few years, especially in the mobile sector. While for fixed service that uses the cable is relatively slower. The use of optical cables on transmission of digital signals into a new energy for telecommunications operators to provide multimedia services in the form of telephone, internet and TV simultaneously with high quality and speed. If the service offered is the third separate, so lately experienced a convergence (Lee dan Cho, 2015) or bundling (Mithat et al., 2015).

Convergence and bundling are two different terms, but refer to a reality that is relatively the same and sometimes interchangeable in the marketing literature studies. Lee and Cho describe convergence as the level of integration of two or more units of a product without tying it to the price, while bundling basically relate to the incorporation of products and prices. Through bundling, the provider offers its services in the format of a dual play (telephone and internet), triple play (an additional TV services) and quadruple play (extra cellular service) (Mithat et al., 2015). TV service in the context of triple play in contrast to pay TV or satellite-based TV broadcast. Internet Protocol Television (IPTV) is the digital TV is transmitted via a copper cable or fiber optics, features are interactive (on demand) and diverse. By 
utilizing the remote device like STB (Set-up Box), it enables users to select the content available as live TV, broadcast delay as well as video (Kim dan Lee, 2013).

As technological innovation and service, bundling IPTV triple play is still relatively new in the paid-TV market of Indonesia. The domestic incumbent operator, PT Telkom has launched the product in December 2013 (Telkom, 2015), but their penetration is still not significant. Entering the year of 2015, Telkom heavily marketed this service with carrying the tagline IndiHome Triple Play 100\% Fiber (Noor, 2015). Although no official release about the number of customers, but the number has exceeded 200 thousand subscribers in March 2015 (Istihanah, 2015).

Zaballos (2013) and Mithat et al. (2015) mentions that the bundling has become a popular strategy for telecommunications operators to maintain and attract new customers, increase customer loyalty and the lever of company's revenue. Then also can withstand the pace of decline in the number of customers churn, displacing and makes price competition became irrelevant as well as inhibiting its aggressive. Bundling can also serve as a tool to attack competitors and self-preservation (Docters et al., 2006), attract new customers and existing customers to retain (Henten dan Godoe, 2010).

A study of the adoption of the technology has been going on a long time, starting from the TAM (Technology Acceptance Model) by Davis et al. (1989) and the perspective of PU (Perceived Usefulness) and EU (Perceived Ease of Use). Gefen et al. (2003) modify TAM by adding a factor of trust variable as the third antecedent. Then trust is seen as a predictor of PU and the EU affect trust, and then all three affect usage intention. Most studies of TAM has an outcome that related to attitude (Al-Jabri dan Roztocki, 2015), behavior (Luo dan Remus, 2014), purchase intention (Kim, 2012) and satisfaction (Al-Jabri, 2015) while dealing with the relative loyalty is still limited. This fact gives the opportunity for researchers to conduct research associated with it.

\section{Literature Review}

Today at least we recognize 3 types of TV service, namely (1) the public TV (Free to Air) broadcast into the air and arrested at home customers using UHF antenna. (2) satellite TV through satellite antenna and (3) network-based internet TV (IPTV) and transmitted to the customers wear copper cable or fiber optics. The last two types are usually paid according the channel package and the content variation of the customers . IPTV is defined by Lin et al. (2012) as broadcasting or on-demand video services by utilizing the internet protocol and is transmitted using the set up box (STB) that can be connected to a personal computer (PC) or television device. The flexibility of the output of the STB, the interactive features and multimedia content are the attractiveness and differentiation of IPTV in comparison to other TV services. That advantage can be an amplifier factor which accelerates the process of his adoption.

The initial study of technology adoption process focuses on two aspects, namely the EU and a PU as proposed by Davis et al. (1989) with the attitude and behavioral as its output. Over time, further study continues to grow with the number of variables, the relationships between variables and expanding output. After TAM, appeared TPB (Planned Behavior Theory) from Ajzen (1991) with the point of views are attitude toward the behavior, Subjective Norm (SN) and Perceived Behavioral Control (PBC). The next antecedent namely trust given by Gefen et al. (2003). The combination and interaction of TAM, TPB and trust analyzed by Wu dan Chen (2005) with the result that only PU and SN are not significant whereas other shows constructs a good relationship. Truong (2013) conducts research in Europe (United Kingdom, Francis and Germany) to analyze and compare the attitude of consumers towards service-based technological innovation. Dimensional measurement using Perceived Novelty (PN), Perceived Value (PV) and the Perceived Risk (PR) as a mediator for Consumer Innovativeness (CI) with the attitude towards innovation. His findings showed that PV and PR support attitude towards innovation while PN instead.

To carry out this study, made a conceptual model of research that was adopted from some earlier research models such as TAM from Davis et al. (1989), modification of TAM with adding of trust variable from Gefen et al. (2003), and model Lin and Wang (2006) linking the relationship between Trust, Satisfaction and Loyalty. 


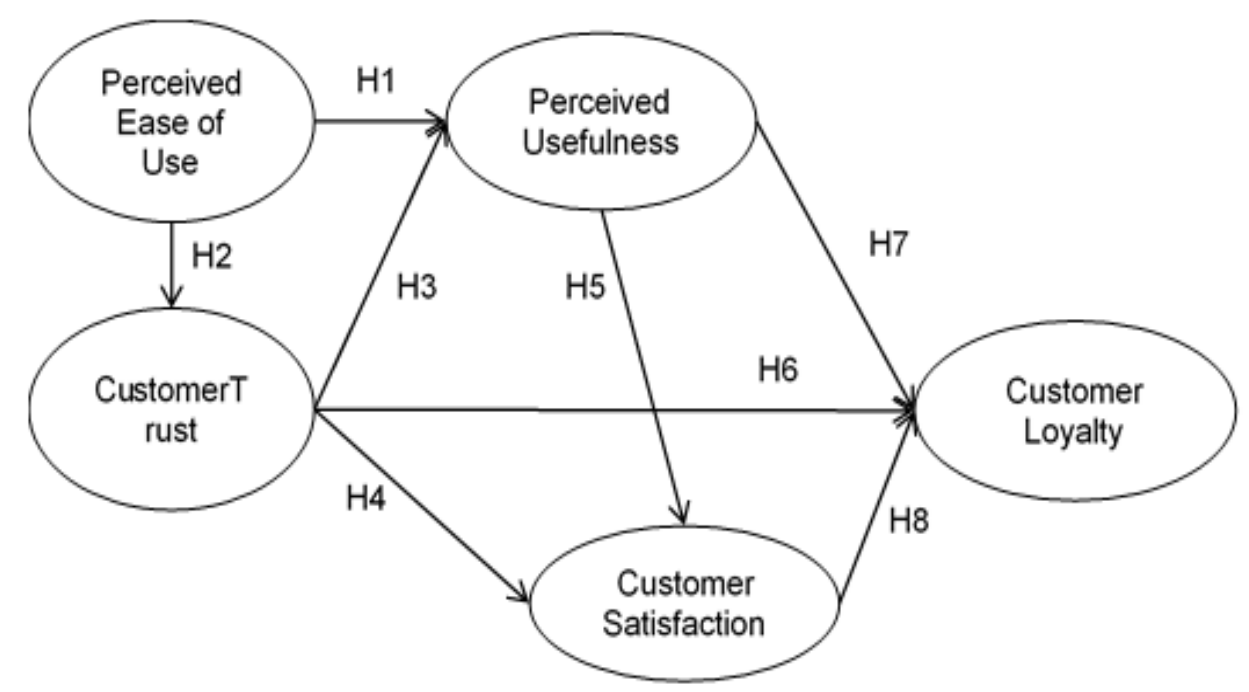

Figure1: Conceptual Model

Research and other articles used as justification to support there is or no relation between constructs in the model and the status of their colleagues. In addition to using the research results from the third party, there are still some other journals that are widely used in this article, like Deng et al. (2010); Hsu et al. (2012) and Tang dan Huang (2015).

\section{Research Methodology}

The population for this study is consumers IPTV Triple play at PT. Telkom in Indonesia. Sample surveys are those who have subscribed to these services more than 3 months thus having sufficient knowledge and experience. The nominal sample required is at least five times the number of observed variables (Ferdinand, 2014). In a conceptual model are listed in Figure 1, there are 5 constructs and each constructs manifested by 4 indicator so the observed total variables is 20 . Because it takes at least 100 samples to meet the minimum criteria expected.

A research questionnaire was compiled using the scale Likert-style with a range of values from 1 to 10 . Number 1 is identical to the answer strongly disagree (SD), number 10 shows the attitude of strongly agree (SA) and the number 5 for the attitude of neutral (N). Each indicator is represented by one grain of questions or statements. The entire question or statement questionnaire is then copied on the Google Form application, so that the final questionnaire available that is ready to be filled by the respondent in the online form. By utilizing e-mail list subscribers gained from Telkom, a detailed questionnaire is then sent to the 250 respondents.

Development of a measurement scale for any constructs adopted from the model and the journal became the reference of this research, however, selected according the relevance of its research objects. For the EU there are 4 indicator variables are referring to the models of (Gefen et al. 2003; Wu dan Chen, 2005;Mulatsih et al., 2017; Isnarno et al., 2018). PU utilize study results (Wu dan Chen, 2005). The next three constructs i.e Trust from Martínez dan Bosque (2013) and (Tang dan Huang, 2015), Satisfaction of the Dagger dan O'Brien (2010) and Amin et al. (2014) as well as the loyalty of Martínez dan Bosque (2013). Table 1 below summarizes in detail of any constructs and its dimensions into the measurement scale. 
Table 1. Composite Reliability and AVE

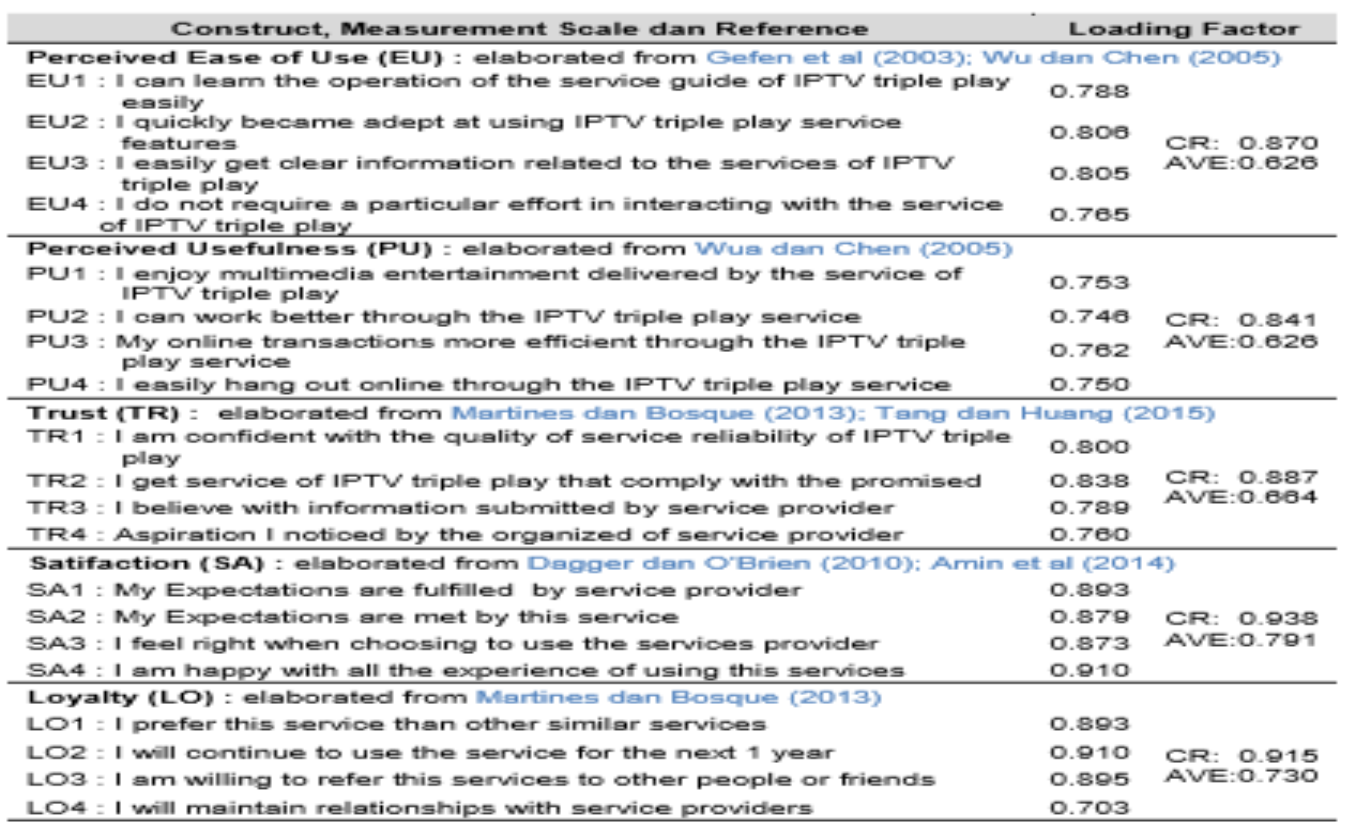

Source : Elaborated from Reference

Reference numbers for CR is $\geq 0.7$, while the AVE is $\geq 0.5$ (Ghozali, 2013), as all tre scores CR nor AVE beyond the value of the specified cut-off point, then reliability constructs is quite good.

\section{Result and Analysis}

Demographic conditions of respondents who participated in this survey based on gender is male $46.6 \%$ and females $25.0 \%$. The proportion of middle and high school education was $13.5 \%$; Diploma $7.3 \%$; Undergraduate $30.4 \%$ and Postgraduate $30.2 \%$. While according to the formation of the work consisted of government employees $4.1 \%$, employees of private sector $16.7 \%$, employees of State Own Company $47.9 \%$, Teachers and Lectures $11.5 \%$, Self-employed $8.3 \%$ and professional $11.5 \%$. From 250 online questionnaire that was distributed via e-mail, there are 147 respondents fill out and return it with a complete and valid answers.

Table 2. Standard Goodness of Fit Index

\begin{tabular}{lccc}
\multicolumn{1}{c}{ Goodness of fit index } & Cut-off Value & Result & Status \\
CMIN $\left(\chi^{2}\right)$ & expected small & 109.921 & FIT \\
Significance Probability & $\geq 0,05$ & 0.008 & Marginal \\
RMSEA & $\leq 0,08$ & 0.054 & Fit \\
GFI & $\geq 0,90$ & 0.915 & Fit \\
AGFI & $\geq 0,90$ & 0.867 & Marginal \\
CMIN/DF & $\leq 2,00$ & 1.428 & Fit \\
TLI & $\geq 0,95$ & 0.974 & Fit \\
CFI & $\geq 0,95$ & 0.587 & Fit \\
\hline
\end{tabular}

Source: Ferdinand (2014)

These data are then simulated using software AMOS with reference to the conceptual model shown in Figure 1. In the SEM (structural equation model) image below, it appears that the number of constructs indicators reduced from the original as much as 20 to 15 . Any constructs experienced a reduction of each 1 indicators, namely the EU4, TR4, PU1, SA3 and LO2. In addition to performing a specific indicator, dropping some error measurement can be in a covariance, the steps taken to improve the overall performance of the model (Ghozali, 2013).

The output of the goodness of fit of the SEM obtained according the diagram above is the probability $(\mathrm{p})=0.008, \mathrm{CMIN}(\chi 2)=109.921$, the CFI $(\mathrm{CMIN} / \mathrm{DF})=1.428, \mathrm{GFI}$, AGFI $=0.915=0.867$, TLI $=0.974, \mathrm{PGFI}=0.587$ and RMSEA $=0.054$. Compared with the standard value of SEM parameter which is 
used as a reference (table 5), then in general the performance model gives satisfactory results, except the numbers probability and TLI tend to be marginal.

Perceived ease of use significantly positive effect against perceived usefulness (H1) with the value of the critical ratio $(\mathrm{CR})$ of 4.170 at the probability level of $<0.1 \%$. So is against the trust $(\mathrm{H} 2)$, perceived ease of use gives positive impact with $\mathrm{CR}=8.556$ and $\mathrm{p}=0000$. Both of these results support previous findings as postulated by (Gefen et al., 2003) and (Wu and Chen, 2005). Further trust shows good performance as the antecedent of perceived usefulness $(\mathrm{H} 3)$, satisfaction $(\mathrm{H} 4)$ and loyalty $(\mathrm{H} 6)$. The same condition, also shown by perceived usefulness as predictors of satisfaction (H5) and loyalty (H7). Next H8 connecting between satisfaction with loyalty, give the level of significance at $p=0.011$ with CR amounted to 2.554 .

The entire relation invalid constructs in the equation in Table 3, the structure is summarized in table form as it appears below.

Perceived ease of use is significantly positive effect on perceived usefulness (H1) with the value of the critical ratio $(\mathrm{CR})$ or $\mathrm{t}$ by 4.170 at a probability level of $<0.1 \%$. Similarly to the trust $(\mathrm{H} 2)$, perceived ease of use have a positive impact with $C R=8.556$ and $p=0.000$. Both results support earlier findings as argued by Gefen et al., (2003) and $\mathrm{Wu}$ and Chen, (2005). Furthermore trusts showed a good performance as the antecedent of perceived usefulness (H3), satisfaction (H4) and loyalty (H6). The same conditions, also shown by the perceived usefulness as a predictor of satisfaction (H5) and loyalty (H7). Furthermore $\mathrm{H} 8$ relation between satisfaction with loyalty give the level of significance at $p=0.011$ with CR amounted to 2.554 .

Relationships entire construct the structure equation model in table 3, is summarized in tabular form as shown below.

Table 3. SEM parameter dan hypotheses Confirmation

\begin{tabular}{|c|c|c|c|}
\hline Hypothesis & Estimate & $\begin{array}{l}\text { CR value } \\
\text { and } P\end{array}$ & $\begin{array}{l}\text { Hypothesis } \\
\text { test }\end{array}$ \\
\hline H1: Perceived Ease of use $\rightarrow$ Perceived Usefulness & 0.563 & $\begin{array}{l}\mathrm{CR}=4.170 \\
\mathrm{P}=.000^{* *}\end{array}$ & Accepted \\
\hline H2: Perceived Ease of use $\rightarrow$ Trust & 0.765 & $\begin{array}{l}\mathrm{CR}=8.566 \\
\mathrm{P}=.000^{* \star}\end{array}$ & Accepted \\
\hline H3: Trust $\rightarrow$ Perceived usefulness & 0.313 & $\begin{array}{l}\mathrm{CR}=2.491 \\
\mathrm{P}=013^{*}\end{array}$ & Accepted \\
\hline H4: Trust $\rightarrow$ Satisfaction & 0.678 & $\begin{array}{l}\mathrm{CR}=7.504 \\
\mathrm{P}=.000^{* \star}\end{array}$ & Accepted \\
\hline H5: Perceived usefulness $\rightarrow$ Satisfaction & 0.272 & $\begin{array}{l}\mathrm{CR}=3.174 \\
\mathrm{P}=002^{*}\end{array}$ & Accepted \\
\hline H6: Trust $\rightarrow$ Loyalty & 0.323 & $\begin{array}{l}\mathrm{CR}=2.073 \\
\mathrm{P}=038^{*}\end{array}$ & Accepted \\
\hline H7: Perceived usefulness $\rightarrow$ Loyalty & 0.227 & $\begin{array}{l}\mathrm{CR}=2.017 \\
\mathrm{P}=044^{*}\end{array}$ & Accepted \\
\hline H8: Satisaction $\rightarrow$ Loyalty & 0.421 & $\begin{array}{l}C R=2.554 \\
P=.011^{*}\end{array}$ & Accepted \\
\hline
\end{tabular}

*Sig $\mathrm{P}<0.05$ and ${ }^{* *}$ Sig $\mathrm{P}<0.001$

\section{Conclusion and Discussion}

From the results of the processing of the survey data and the existing conceptual model, it can be noted that all of the hypotheses put forward in this study support and proven significant positive relation in their structural equation on each. Based on these findings, some things can be summed up as follows : Perceived ease of use is the antecedent of perceived usefulness and Trust. In the context of Triple play IPTV service, ease of operation features of the service, the user manual that is easily learned, availability of information and interaction that does not require a particular effort from customers will affect the level of trust and the perception of the effectiveness of the product concerned.

Satisfaction was the mediator for the trust and perceived usefulness, as well as trust and perceived usefulness that is able to be intervening for the perceived ease of use.

Trust has a direct effect on loyalty and an indirect effect through perceived usefulness or satisfaction. The direct impact of trust on loyalty is equal to 0.323 , while through mediation of perceived usefulness is at 0.071 (path TR --> PU multiplied by path PU --> LO) and when using mediation of satisfaction is 0.258 (path TR --> SA multiplied by track SA --> LO). The total effect of trust on loyalty to the perceived usefulness of mediation is 0.394 , while mediation through satisfaction is 0.581 . In this case, the direct effect and mediation using satisfaction more effective than utilizing perceived usefulness as an intervening variable. 
Synthesis of simulated models have demonstrated that there is a significant positive correlation between cognitive (EU, TR and PU), conative (SA) and affective (LO) aspects in consumer behavior for IPTV Tripleplay (IndiHome) services.

In the academic perspective, the results in this study reinforce the findings of previous studies and simultaneously increase marketing academic literature in the field of technology adoption and consumer behavior. The role of perceived ease of use as an antecedent of trust and perceived usefulness support the results of a study by (Gefen et al., 2003), (Wu dan Chen, 2005) and (Tung et al., 2008). Similarly, the relationship between trust and perceived usefulness, also gave support to the three prior research result. The relationship of trust towards the satisfaction of having a high correlation coefficient, that is 0.678 with level of significance $\mathrm{p}<0.01 \%$. With these conditions, it can be said that consumer confidence had a great influence towards the creation of consumer satisfaction. This is similar to the results of research (Deng et al., 2010; Liaw, 2013; Vahedi et al., 2014; Tang dan Huang, 2015).

Furthermore the findings of this study also revealed that trust, perceived usefulness and satisfaction is the antecedent for loyalty. Third of those relationships, it is known that the variable satisfaction most strongly influencing to loyalty, then followed by trust and perceived usefulness. The dominance of the influence of satisfaction on loyalty, relevant to some relatively new study results like Lee dan Kwon (2011); Tam (2012); Martínez dan Bosque (2013); dan Tang dan Huang (2015). IPTV technology in Indonesia is relatively new and only operated by several operators with dualplay services (Internet and digital TV) and Tripleplay (Telephone, Internet and digital TV). Under these conditions, all providers need information and scientific empirical study as a reference to get to know the characters and the market response associated with the adoption process, confidence, satisfaction and loyalty. Without an adequate understanding of these variables, IPTV operators will be difficult to penetrate the market and won the competition.

Study findings showed that the adoption of IPTV Triple play technology through components of perceived ease of use is very strong influence on consumer confidence. The inability of the operator to fix the dimensions associated with it will reduce the speed of adoption by consumers of products. The same condition could occur if the impact of perceived ease of use of the perceived usefulness less handled properly. Indications of this statement can be seen from the influence of perceived ease of use to the perceived usefulness is 0.563 with a significance level at $\mathrm{p}<0.01 \%$.

To survive and Excel in competition, IPTV providers can evaluate the aspects of being a weak point in the context of trust, satisfaction and loyalty of consumers. Reflect on the findings of this study, the confidence factor had a large role in increasing consumer satisfaction, trust and satisfaction variables simultaneously affecting the degree of consumer loyalty.

\section{References}

Ajzen, I. 1991. "The Theory of Planned Behavior". Organizational Behavior and Human Decision Processes, 50,179-211. https://doi.org/10.1016/0749-5978(91)90020-T

Al-Jabri, I. M. 2015. "Antecedents of user satisfaction with ERP systems, mediation analyses". Kybernetes, 44 (1), 107123. https://doi.org/10.1108/K-05-2014-0101

Al-Jabri, I. M., and N. Roztocki. 2015. "Adoption of ERP systems: Does information transparency matter?". Telematics and Informatics, 32(2),300-310. https:/ / doi.org/10.1016/j.tele.2014.09.005

Amin, M., S. Rezaei, and M. Abolghasemi. 2014. "User satisfaction with mobile websites: the impact of perceived usefulness (PU), perceived ease of use (PEOU) and trust". Nankai Business Review International, 5(3), $258-274$. https://doi.org/10.1108/NBRI-01-2014-0005

Baier, D., and E. Stüber. 2010. "Acceptance of recommendations to buy in online retailing". Journal of Retailing and Consumer Services, 17(3),173-180. https:/ / doi.org/10.1016/j.jretconser.2010.03.005

Carter, M., R. Wright, J. B. Thatcher, and R. Klein. 2012. "Understanding online customers' ties to merchants: the moderating influence of trust on the relationship between switching costs and e-loyalty". European Journal of Information Systems, 23(2), pp: 185-204. https://link.springer.com/article/10.1057/ejis.2012.55

Chauhan, S. 2015. "Acceptance of mobile money by poor citizens of India, integrating trust into the technology acceptance model". Info, 17(3) https://doi.org/10.1108/info-02-2015-0018

Choi, B., and S. La. 2013. "The impact of corporate social responsibility (CSR) and customer trust on the restoration of loyalty after service failure and recovery". Journal of Services Marketing, 27(3), 223 - 233. https://doi.org/10.1108/08876041311330717 
Cyr, D., M. Head, and A. Ivanov. 2009. "Perceived interactivity leading to e-loyalty: Development of a model for cognitive-affective user responses". International Journal of Human-Computer Studies, 67(10), 850-869. https://doi.org/10.1016/j.ijhcs.2009.07.004

Dagger, T. S., and T. K. O'Brien. 2010. "Does experience matter? Differences in relationship benefits, satisfaction, trust, commitment and loyalty for novice and experienced service users". European Journal of Marketing, 44(9/10),1528-1552. https:// doi.org/10.1108/03090561011062952

Davis, F. D., R. P. Bagozzi, and P. R. Warshaw. 1989. "User Acceptance of Comuter Technology, a Comparison of Two Theoretical Models". Management Science, 35(8), https://doi.org/10.1287/mnsc.35.8.982

Deng, Z., Y. Lu, K. K. Wei, and J. Zhang. 2010. "Understanding customer satisfaction and loyalty: An empirical study of mobile instant messages in China". International Journal of Information Management, 30(4), $289-300$. https:// doi.org/10.1016/j.ijinfomgt.2009.10.001

Docters, R., B. Schefers, C. Durman, and M. Gieskes. 2006. "Bundles with sharp teeth, effective product combinations". Journal of Business Strategy, 27(5), 10-16. https:/ / doi.org/10.1108/02756660610692653

Eid, M. I. 2011. "Determinants of E-Commerce Customer Satisfaction, Trust, and Loyalty in Saudi Arabia". Journal of Electronic Commerce Research, Vol. 12, No. 1,.

https:/ / search.proquest.com/openview/e2638a87737aea8cba164bc857a05194/1?pq origsite $=$ gscholar\&cbl=44515

Fatimah, F., Rosadi, D., Hakim, R. F., \& Alcantud, J. C. R. (2017, July). A social choice approach to graded soft sets. In Fuzzy Systems (FUZZ-IEEE), 2017 IEEE International Conference on (pp. 1-6). IEEE. 10.1109/FUZZIEEE.2017.8015428

Ferdinand, A. T. 2014. Structural Equation Model Dalam Penelitian Manajemen, Aplikasi Model-Model Rumit Dalam Penelitian Untuk Skripsi, Tesis dan Disertasi Doktor. In Seri Pustaka Kunci, edited by F. E. d. B. U. Diponegoro. Semarang, Indonesia: BP Undip-Undip Press

Gallarza, M. G., and I. Gil Saura. 2006. "Value dimensions, perceived value, satisfaction and loyalty: an investigation of university students' travel behaviour". Tourism Management, 27(3), 437-452.

https://doi.org/10.1016/j.tourman.2004.12.002

Gefen, D., E. Karahanna, and D. W. Straub. 2003. "Trust and TAM in Online Shopping-An Integrated Model". MIS Quarterly, 27(1),51-90. https:// dl.acm.org/citation.cfm?id=2017185

Ghozali, I. 2013. Model Persamaan Struktural, Konsep dan Aplikasi Dengan Program AMOS 21.5 ed. Semarang, Indonesia: Badan Penerbit Undip.

Haghighi, M., A. Dorosti, A. Rahnama, and A. Hoseinpour. 2012. "Evaluation of factors affecting customer loyalty in the restaurant industry". African Journal of Business Management, 6, (14), 5039-5046.

Henten, A., and H. Godoe. 2010. "Demand side economies of scope in bundled communication services". Info, $12(1), 26$ - 38. https:/ / doi.org/10.1108/14636691011015367

Hsu, C.-L., C.-C. Wu, dan M.-C. Chen. 2012. "An empirical analysis of the antecedents of e-satisfaction and e-loyalty: focusing on the role of flow and its antecedents". Information Systems and e-Business Management, 11(2),287-311. https://link.springer.com/article/10.1007/s10257-012-0194-8

Isnarno, E., Soesanto, H., \& Andriyansah. (2018). Developing the Reputation of Distribution Network to Increase the Buying Interest of Electronic Payment: An Empirical Study. European Research Studies Journal, XXI( 1), 133 - 143.

Istihanah. 2015. "Solusi Digital bagi Keluarga Indonesia" http://swa.co.id/business-strategy/indihome-solusi-digital-bagikeluarga-indonesia. [accessed on May 17 2015].

Kim, J., and S. Forsythe. 2009. "Adoption of sensory enabling technology for online apparel shopping". European Journal of Marketing, 43(9/10),1101 - 1120. https:/ / doi.org/10.1108/03090560910976384

Kim, J., and K. H. Lee. 2013. "Towards a theoretical framework of motivations and interactivity for using IPTV". Journal of Business Research, 66(2),260-264. https://doi.org/10.1016/j.jbusres.2012.07.004

Kim, J. B. 2012. "An empirical study on consumer first purchase intention in online shopping: integrating initial trust and TAM". Electronic Commerce Research, 12(2),125-150. https://link.springer.com/article/10.1007/s10660-0129089-5

Lee, M.-C. 2009. "Predicting and explaining the adoption of online trading: An empirical study in Taiwan". Decision Support Systems, 47, 133-142. https://doi.org/10.1016/j.dss.2009.02.003

Lee, M., and Y. Cho. 2015. "Consumer perception of a new convergence product: A theoretical and empirical approach". Technological Forecasting and Social Change, 92, 312-321.

https://doi.org/10.1016/j.techfore.2014.12.006

Lee, Y., and O. Kwon. 2011. "Intimacy, familiarity and continuance intention: An extended expectation-confirmation model in web-based services". Electronic Commerce Research and Applications, 10(3), 342-357.

https://doi.org/10.1016/j.elerap.2010.11.005

Liaw, G.-F. 2013. "The Effect of Trust, Satisfaction, and Switching Cost on Consumer's Loyalty - A Model of On-line Auction". The Journal of International Management Studies, 8(1) 
Liébana-Cabanillas, F., J. Sánchez-Fernández, and F. Muñoz-Leiva. 2014. "Antecedents of the adoption of the new mobile payment systems: The moderating effect of age". Computers in Human Behavior, 35, 464-478.

https://doi.org/10.1016/j.chb.2014.03.022

Lin, T.-C., S. Wu, J. S.-C. Hsu, and Y.-C. Chou. 2012. "The integration of value-based adoption and expectationconfirmation models: An example of IPTV continuance intention". Decision Support Systems, 54(1), 63-75.

https://doi.org/10.1016/j.dss.2012.04.004

Lorenzo-Romero, C., E. Constantinides, and M. a.-d.-C. Alarcon-del-Amo. 2011. "A model of the adoption of radio frequency identification technology, implication for theory and practice". Journal of Research in Interactive Marketing, 5(2/3),170 - 188. https://doi.org/10.1016/j.jengtecman.2011.09.010

Luo, M. M., and W. Remus. 2014. "Uses and gratifications and acceptance of Web-based information services: An integrated model". Computers in Human Behavior, 38, 281-295. https://doi.org/10.1016/j.chb.2014.05.042

Martínez, P., and R. d. I. Bosque. 2013. "CSR and customer loyalty: The roles of trust, customer identification with the company and satisfaction". International Journal of Hospitality Management, 35, 89-99.

https://doi.org/10.1016/j.ijhm.2013.05.009

Miquel-Romero, M. J., E. M. Caplliure-Giner, and C. Adame-Sánchez. 2014. "Relationship marketing management: Its importance in private label extension". Journal of Business Research, 67(5), 667-672.

https://doi.org/10.1016/j.jbusres.2013.11.025

Mithat, Ü. M., F. Güven, and S. Tamer Cavusgil. 2015. "Bundling of telecom offerings: An Empirical Investigation in the Turkish market". Telecommunications Policy, 39(1), 53-64. https://doi.org/10.1016/j.telpol.2014.12.004

Mulatsih, R., Andriyansah, \& Soesanto, H. (2017). Corporate Image of Bus Rapid Transit Antecedent Customer Repurchase Intention. International Journal of Applied Engineering Research, 12(18), 7734-7740

doi:https://www.ripublication.com/ijaer17/ijaerv12n18_84.pdf

Nguyen, N., A. Leclerc, and G. LeBlanc. 2013. "The Mediating Role of Customer Trust on Customer Loyalty". Journal of Service Science and Management, 06(01),96-109. http:/ / dx.doi.org/10.4236/jssm.2013.61010

Noor, A. R. 2015. "Setelah Triple Play, Telkom Siap Loncat ke Octuple Play"

http://inet.detik.com/read/2015/03/18/191316/2862837/328/1/setelah-triple-play-telkom-siap-loncat-ke-octuple-play.

Pongcharnchavalit, S., and W. Fongsuwan. 2014. "Structural equation model of customer perception of service and product quality factors that affects Thai information technology customer loyalty". Research Journal of Business Management, 8(4),412-426. http:/ / docsdrive.com/pdfs/academicjournals/rjbm/2014/412-426.pdf

Ruiz-Mafe, C., J. Mart1'-Parreno, and S. Sanz-Blas. 2014. "Key drivers of consumer loyalty to Facebook fan pages". Online Information Review, 38(3),362-380. https:/ / doi.org/10.1108/OIR-05-2013-0101

Sahin, A., C. Zehir, and H. Kitapçı. 2011. "The Effects of Brand Experiences, Trust and Satisfaction on Building Brand Loyalty; An Empirical Research On Global Brands". Procedia - Social and Behavioral Sciences, 24, $1288-1301$. https://doi.org/10.1016/j.sbspro.2011.09.143

Tam, J. L.-M. 2012. "The moderating role of perceived risk in loyalty intentions: an investigation in a service context". Marketing Intelligence E Planning, 30(1),33-52. https:/ / doi.org/10.1108/02634501211193903

Tang, T.-W., and R.-T. Huang. 2015. "The Relationships among Trust, E-satisfaction, E-loyalty, and Customer Online Behaviors". International Journal of Business and Industrial Marketing, 1(2), 16-25.

http:/ /iceb.nccu.edu.tw/proceedings/2005/788-794.pdf

Telkom. 2015. "IndiHome Targetkan 3 Juta Pelanggan di 2015" http://www.indihome.co.id/article/detail/indi-hometargetkan-3-juta-pelanggan-di-2015-. [accessws on May 17 2015].

Truong, Y. 2013. "A cross-country study of consumer innovativeness and technological service innovation". Journal of Retailing and Consumer Services, 20(1),130-137. https:/ / doi.org/10.1016/j.jretconser.2012.10.014

Tung, F. C., S. C. Chang, and C. M. Chou. 2008. "An extension of trust and TAM model with IDT in the adoption of the electronic logistics information system in HIS in the medical industry". Int J Med Inform, 77(5), $324-335$. https://doi.org/10.1016/j.ijmedinf.2007.06.006

Vahedi, E., A. Shirian, F. SadeghVaziri, E. R. Kelishmi, and S. Esmaeili. 2014. "Assessing the Role of Brand Personality on Trust, Affection, Loyalty and Customer Satisfaction in Governmental Organization: (Case of Study: Maskan Bank)". Research Journal of Recent Sciences, 3(7),130-138. http:/ / dr-shirian.com/wp-

content/uploads/2017/12/Revised-Research-Paper-ISCA-RJRS-2013-735.pdf

Wu, I.-L., and J.-L. Chen. 2005. "An extension of Trust and TAM model with TPB in the initial adoption of on-line tax: An empirical study". International Journal of Human-Computer Studies, 62(6) 784-808.

https://doi.org/10.1016/j.ijhcs.2005.03.003

Zaballos, A. G. 2013. "Impact of bundling of ICT services on regulation". Info, 15(4),69-78

. https://doi.org/10.1108/info-12-2012-0053

Zehir, C., A. Şahin, H. Kitapçı, and M. Özşahin. 2011. "The Effects of Brand Communication and Service Quality In Building Brand Loyalty Through Brand Trust; The Empirical Research On Global Brands". Procedia - Social and Behavioral Sciences, 24, 1218-1231. https:// doi.org/10.1016/j.sbspro.2011.09.142 